\title{
Erişkin Bir Hastada Hemofagositik Lenfohistiyositoz ve Viseral Leyşmanyazis
}

\author{
Visceral Leishmaniasis and Hemophagocytic \\ Lymphohistiocytosis in an Adult Patient
}

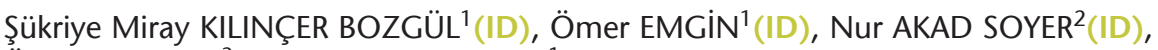

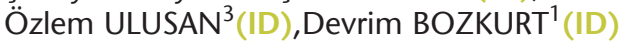 \\ ${ }^{1}$ Ege Üniversitesi Tıp Fakültesi, İç Hastalıkları Anabilim Dalı, İzmir. \\ 1 Ege University Faculty of Medicine, Department of Internal Medicine, Izmir, Turkey. \\ 2 Ege Üniversitesi Tıp Fakültesi, İç Hastalıkları Anabilim Dalı, Hematoloji Bilim Dalı, İzmir. \\ 2 Ege University Faculty of Medicine, Department of Internal Medicine, Division of Hematology, Izmir, Turkey. \\ ${ }^{3}$ Ege Üniversitesi Tıp Fakültesi, Tıbbi Parazitoloji Anabilim Dalı, İzmir. \\ 3 Ege University Faculty of Medicine, Department of Medical Parasitology, Izmir, Turkey.
}

Makale Atıfı: Kılınçer Bozgül ŞM, Emgin Ö, Akad Soyer N, Ulusan Ö, Bozkurt D. Erişkin bir hastada hemofagositik lenfohistiyositoz ve viseral leyşmanyazis. Mikrobiyol Bul 2020;54(2):339-346.

\section{ÖZ}

Leyşmanyazis, Antarktika hariç tüm kıtalarda görülebilen vektör kum sinekleri (yakarca) aracılığı ile bulaşan zoonotik paraziter hastalıktır. Akdeniz Havzasındaki ülkelerde (Türkiye, Suriye, Kuzey Afrika ülkeleri, Ürdün, İtalya, İspanya, İran) sık rastlanan bir enfeksiyon hastalığıdır. Leyşmanyazis; kutanöz, mukokutanöz ve viseral leyşmanyazis (VL) şeklinde üç klinik formda karşımıza çıkabilir. VL, ülkemizde Akdeniz ve Ege bölgelerinde endemik, diğer bölgelerde ise sporadik olarak görülmektedir. Bu raporda İzmir'de ikamet eden VL'ye ek olarak hemofagositik lenfohistiyositoz (HLH) gelişen bir olgu sunulmuştur. Elli yaşında kadın hasta yaklaşık 3 hafta önce başlayan ve artarak devam eden ateş, terleme, halsizlik, yorgunluk şikayetleri ile hastaneye başvurmuştur. Fizik muayenesinde ateşi $38.7^{\circ} \mathrm{C}$ ölçülmüştür. Hastanın yapılan hemogramında hemoglobin: $8.91 \mathrm{~g} / \mathrm{dl}(11.7-16.0)$, trombosit sayısı: $10^{4} \times 10^{3} / \mu \mathrm{l}$ (150-450), lökosit sayısı: $1.3510^{3} / \mu \mathrm{l}(4.5-11)$ şeklinde pansitopeni saptanmıştır. Batının ultrasonografik değerlendirmesinde hepatosplenomegali saptanmıştır. Laboratuvar tetkiklerinde ferritin: $764.4 \mathrm{ng} / \mathrm{ml}$ (13-150) ve trigliserit düzeyi $232 \mathrm{mg} / \mathrm{dl}(<150)$ şeklinde artmış olarak saptanmıştır. 2004 yılı HLH tanı kriterleri rehberine göre hastaya HLH tanısı konulmuştur. HLH'ye neden olabilecek sekonder hastalıklar açısından hasta araştırıımıştır. Kemik iliği aspirasyonunda hemofagositoz ve intraselüler parazitler gözlenmiştir. Yapılan leyşmanyazis indirekt floresan antikor IgG testi (IFAT) 1/1024 titrede pozitif olarak saptanmıştır. Ayrıca, hastadan alınan kemik iliği aspirasyon örneğinde polimeraz zincir reaksiyonu ile leyşmanya varlığı aranmış ve etkenin Leishmania infantum olduğu tespit edilmiştir. Hasta VL'ye sekonder olarak gelişen HLH olgusu olarak değerlendirilmiş ve lipozomal amfoterisin B tedavisi uygulanmışır. Tedavinin 5. gününde hastanın ateş yüksekliği şikayeti kaybolmuş, halsizlik, yorgunluk, terleme şikayetlerinde belirgin azalma olmuştur. Tedavi sonrası 2. ay kontrolünde şikayetlerinin tamamen kaybolduğu ve pansitopenisinin düzeldiği görülmüştür. HLH ve VL erken tanınıp tedavi edilmediğinde 
ölümcül olabilen hastalıklardır. Sitopeni, yüksek ferritin ve trigliserit düzeyi, düşük fibrinojen düzeyi, ateş olması durumunda HLH akla gelmeli ve sekonder nedenlerin araştırılmasında paraziter etkenler de unutulmamalıdır. Bu olgu sunumu ile leyşmanyazisin çok nadir bir klinik şekli olan HLH tanısına dikkat çekilmesi amaçlanmıştır.

Anahtar kelimeler: Hemofagositoz; hemofagositik lenfohistiyositoz; leyşmanyazis; viseral leyşmanyazis.

\section{ABSTRACT}

Leishmaniasis is a vector borne zoonotic parasitic disease transmitted by sand flies and it can be seen in all continents except Antarctica. It is a common disease in the countries located in Mediterranean basin (Turkey, Syria, North Africa, Jordan, Italy, Iran). It may present with three clinical forms such as cutaneous, mucocutaneous visceral leishmaniasis (VL). VL is an endemic disease in the Mediterranean and Aegean regions of Turkey and it is seen sporadically in the other regions. In this report a case who is living in Izmir province with hemophagocytic lymphohistiocytosis $(\mathrm{HLH})$ secondary to $\mathrm{VL}$ was presented. A 50-year-old woman admitted to our department with fever, weakness, sweating and fatique for about three weeks. The patient's temperature was $38.7^{\circ} \mathrm{C}$. Laboratory tests revealed pancytopenia with hemoglobin level of $8.91 \mathrm{~g} / \mathrm{dl}(11.7-16.0 \mathrm{~g} / \mathrm{dl})$, platelet level $10^{4} \times 10^{3} / \mu \mathrm{l}\left(150-450 \times 10^{3} / \mu \mathrm{l}\right)$ and leukocyte $\left(1.35 \times 10^{3} /\right.$ $\mu \mathrm{l}\left(4.5-11 \times 10^{3} / \mu \mathrm{l}\right)$ counts. Ferritin and triglyceride levels were increased. Ferritin level was $764.4 \mathrm{ng} /$ $\mathrm{ml}\left(13-150 \times 10^{3} / \mu \mathrm{l}\right)$ and triglyceride level was $232 \mathrm{mg} / \mathrm{dl}(<150 \mathrm{mg} / \mathrm{dl})$. HLH was diagnosed according to the $2004 \mathrm{HLH}$ current diagnostic guidelines. After this diagnosis the patient was investigated for underlying disease such as malignancy, autoimmune diseases, medications and infectious diseases. Bone marrow aspiration showed hemophagocytosis and intracellular Leishmania amastigotes. Leishmania indirect fluorescent antibody IgG (IFAT) was positive in titre of (1/1024). In addition, in the bone marrow aspiration sample taken from the patient, the causative agent of leishmaniasis was searched by polymerase chain reaction, and it was determined that etiological agent was Leishmania infantum. The patient was evaluated as HLH secondary to VL. Liposomal amphotericin B therapy was started and in the $5^{\text {th }}$ day of treatment, the patient's fever was measured as normal. There was a significant decrease in fatigue and sweating. After two months of treatment, the complaints disappeared completely and hemoglobin, leukocyte, platelet counts were found normal. HLH and VL can be fatal if they are not early diagnosed and treated. Physicians must be alert for HLH when cytopenia, uncontrolled fever, high triglyceride and high ferritin level and parasitological tests should be done for possible underlying disease. In this case report, we aimed to draw attention to the diagnosis of $\mathrm{HLH}$, which is a very rare clinical presentation of leishmaniasis.

Keywords: Hemophagocytosis; hemophagocytic lymphohistiocytosis; leishmaniasis; viceral leishmaniasis.

\section{Giriş̧}

Olguların \%90'dan fazlasının Bangladeş, Hindistan, Nepal, Sudan ve Brezilya'da görülmesine rağmen leyşmanyazis, Antarktika hariç tüm kıtalarda görülebilen, kum sinekleri (yakarca) aracılığı ile bulaşan zoonotik paraziter hastalıktır. Hintçe kara ateş anlamına gelen kala-azar olarak da bilinen viseral leyşmanyazis $(\mathrm{VL})$, çoğunlukla Leishmania donovani ve Leishmania infantum gibi parazitlerin kum sineği aracılığıyla insana bulaşması sonucu meydana gelmektedir. Akdeniz havzasında yer alan ülkelerde sık rastlanan bir enfeksiyon hastalığıdır ${ }^{1}$. VL ülkemizde Akdeniz ve Ege bölgelerinde endemik, diğer bölgelerde ise sporadik olarak görülmektedir ${ }^{2}$. L.donovani ve L.infantum'un neden olduğu başlıca klinik bulgular genellikle özel tetkikler olmadıkça ayırt edilememektedir. VL tamamen asemptomatik seyredebilirken iç organları tutarak halsizlik, kilo kaybı, ateş, hepatosplenomegali, lenfadenomegali, trombositopeni, lökopeni, anemi gibi durumlar yaratabilmektedir. 
Nadiren ani gelişen şikayetleri olduğunu belirten hastalar olsa da, bu enfeksiyonda genellikle ateş, kilo kaybı gibi semptomların aylar öncesinden var olduğu belirtilmektedir ${ }^{3}$.

Hemofagositik lenfohistiyositoz (HLH), aşırı immün aktivasyon nedeniyle hızla gelişen, hayatı tehdit eden bir sendromdur. HLH genetik (primer) ve kazanılmış (sekonder) nedenlerle ortaya çıkabilmektedir. Sekonder nedenler olarak en sık viral enfeksiyonlar karşımıza çıkmaktadır ${ }^{4}$. Viral (en sık Epstein-Barr virüs) ${ }^{5}$, bakteriyel (en sık Mycobacterium tuberculosis) ${ }^{4}$, mantar ve paraziter (en sık Leishmania, Histoplasma, Toxoplasma) ${ }^{4}$ enfeksiyonların yanı sıra sıklıkla hematolojik malignansiler ${ }^{6}$, radikal stres, metabolik hastalıklar, immün yetmezlik ve romatolojik hastalıklar (en sık Still hastalığı) ${ }^{7} \mathrm{HLH}^{\prime}$ nin sekonder nedenleridir. Primer HLH bir pediatrik sendromdur, sıklıkla üç ayın altındaki infantlarda görülmektedir ${ }^{8}$. Sekonder HLH ise her yaştaki hastalarda görülebilir ${ }^{9-11}$. Ateş ve hepatosplenomegali en sık bulgular olmasına karşıık, sarılık, lenfadenomegali, konvülziyon, hemodinamik instabilite, koagülasyon bozuklukları, solunum yetmezliği gibi bulgular da görülebilir. Laboratuvar tetkiklerinde sitopeni, düşük fibrinojen düzeyi ve yüksek ferritin, trigliserit ve laktat dehidrogenaz düzeyi sık tespit edilen bulgulardır ${ }^{12}$. Ateş, sitopeni ve hızla gelişebilecek çoklu organ yetmezliği kliniği ile sıklıkla sepsis ve sistemik enflamatuvar yanıt sendromu (SIRS) tanısı alıp bu yönde tedavi edildiğinden tanıda gecikmeler olmakta ve mortalite artmaktadır. HLH'nin tanı kriterleri ve hastamızda ortaya çıkan bulgular Tablo I'de verilmiştir. Bu raporda, VL'ye sekonder gelişen HLH olgusu literatürle karşılaştırılarak sunulmuştur.

Tablo I. Hemofagositik Lenfohistiyositoz Tanı Kriterleri

A. Ailevi hastalık/bilinen genetik defekt

B. Klinik ve laboratuvar tanı kriterleri

1. Ateş $\left(>7\right.$ gün, $\left.>38.5^{\circ} \mathrm{C}\right)$ **

2. Splenomegali**

3. Sitopeni (en az iki hücre serisi)**

Hemoglobin $<9 \mathrm{~g} / \mathrm{dl}$ (dört haftanın altında $12 \mathrm{~g} / \mathrm{dl}$ )

Trombositler $<100 \times 10^{9} / \mathrm{L}$

Nötrofiller $<1 \times 10^{9} / \mathrm{L}$

4. Ferritin $>500 \mu \mathrm{g} / \mathrm{L}^{* *}$

5. $\mathrm{sCD} 25>2400 \mathrm{U} / \mathrm{ml}$

6. Hipertrigliseridemi ve/veya hipofibrinojenemi**

Açlık trigliseridi $>3 \mathrm{mmol} / \mathrm{L}$

Fibrinojen $<1.5 \mathrm{~g} / \mathrm{L}$

7. Natural killer hücre aktivitesinin azalması veya hiç olmaması

8. Kemik iliği, beyin omurilik sıvısı veya lenf bezlerinde hemofagositoz**

* Tanı için ailevi hastalık/bilinen gen defekti varlığı veya sekiz klinik ve laboratuvar tanı kriterinden en az beşinin olması gereklidir.

** Hastamızda mevcut olan klinik ve laboratuvar bulgular. 


\section{OLGU SUNUMU}

Acil servise ateş yüksekliği, terleme, halsizlik şikayetleri ile başvuran 50 yaşında kadın hastanın öyküsünde evli ve 2 çocuğu olduğu, İzmir-Çiğli'de yaşadığı, ev hanımı olduğu, bu şikayetlerinin yaklaşık 3 hafta önce başladığı ve artarak devam ettiği, herhangi bir ilaç kullanımı veya operasyon öyküsünün olmadığı tespit edildi. Fizik muayenesinde genel durumu orta, soluk görünümde olduğu görüldü. Hepatomegalisi olan ve Traube alanı kapalı olan hastada periferik lenfadenopati saptanmadı. Kan basıncı 80/50 mmHg, nabız 115/ dakika, vücut sıcaklığı $38.7^{\circ} \mathrm{C}$ olarak ölçüldü. Hasta SIRS bulgularıyla yoğun bakıma yatırıldı. Illk laboratuvar sonuçlarında hemoglobin düzeyi: $8.91 \mathrm{~g} / \mathrm{dl}(11.7-16.0 \mathrm{~g} / \mathrm{dl})$, ortalama eritrosit hacmi (MCV) $76.9 \mathrm{fl}(81-101 \mathrm{fl})$, trombosit sayısı $10^{4} \times 10^{3} / \mu \mathrm{l}\left(150-450 \times 10^{3} / \mu \mathrm{l}\right)$, lökosit sayısı 1350/ $\mu \mathrm{L}(4.5-11 \mu \mathrm{l})$ olup; periferik yaymada eritrositler hipokrom, normositer, formülünde lökopenik ve trombositler azalmış görüldü. Vitamin B12 düzeyi $456 \mathrm{ng} / \mathrm{L}$ (197-866 ng/L), folik asit düzeyi $7.85 \mu \mathrm{g} / \mathrm{L}$ (3.89-26.8 $\mu \mathrm{g} / \mathrm{L})$, ferritin 764.4 ng/ml (13-150 $\mathrm{ng} / \mathrm{ml}$ ) geldi. C-reaktif protein $3.38 \mathrm{mg} / \mathrm{dl}(0-0.05 \mathrm{mg} / \mathrm{dl})$ ve prokalsitonin $0.08 \mu \mathrm{g} / \mathrm{L}$ (< $0.05 \mu \mathrm{g} / \mathrm{L})$ bulundu. Batın ultrasonografisinde hepatomegali $(16 \mathrm{~cm})$, splenomegali $(16$ $\mathrm{cm}$ ) dışında patoloji izlenmedi. Trigliserit düzeyi $232 \mathrm{mg} / \mathrm{dl}(<150 \mathrm{mg} / \mathrm{dl})$ olarak sonuçlandı. Diğer biyokimya tetkik sonuçları ve koagülasyon testleri normal bulundu. $2004 \mathrm{HLH}$ tanı kriterleri rehberi temel alınarak hastaya HLH tanısı konuldu.

İkincil nedenler olarak malignite, enfeksiyon etkenleri, otoimmün hastalıklar, ilaçlar araştırıldı. Hemofagositoza neden olabilecek ilaç kullanım öyküsü gözlenmedi. Antinükleer antikor (ANA), antinötrofil sitoplazmik antikor (ANCA), romatoid faktör (RF) negatif olarak saptandı. Fizik muayene ve radyolojik görüntüleme ile değerlendirilen hastada solid organ malignitesine yönelik herhangi bir bulguya rastlanmadı. HBsAg, anti-HCV, anti-HIV negatif olarak saptandı. Sitopenisi ve ateş yüksekliği nedeniyle yapılan kemik iliği aspirasyon örneğinde tüberküloz lehine bulgu saptanmadı. Aspirasyonda selülaritede artış izlendi, hemofagositoz ve iki alanda intraselüler paraziter görüntüler izlendi (Resim 1).

Hastanın serum örneğine Ege Üniversitesi Tıp Fakültesi Tıbbi Parazitoloji Anabilim Dalı Seroloji Laboratuvarında hazırlanan immün floresan antikor testi (IFAT) uyguland ${ }^{13}$ ve anti-Leishmania IgG antikorları testin üst limitinde (1/1024 seyreltme) pozitif saptandı. IFAT'ta kullanılan pozitif serum örneğinin 1/16 seyreltmede floresan mikroskop görüntüsü
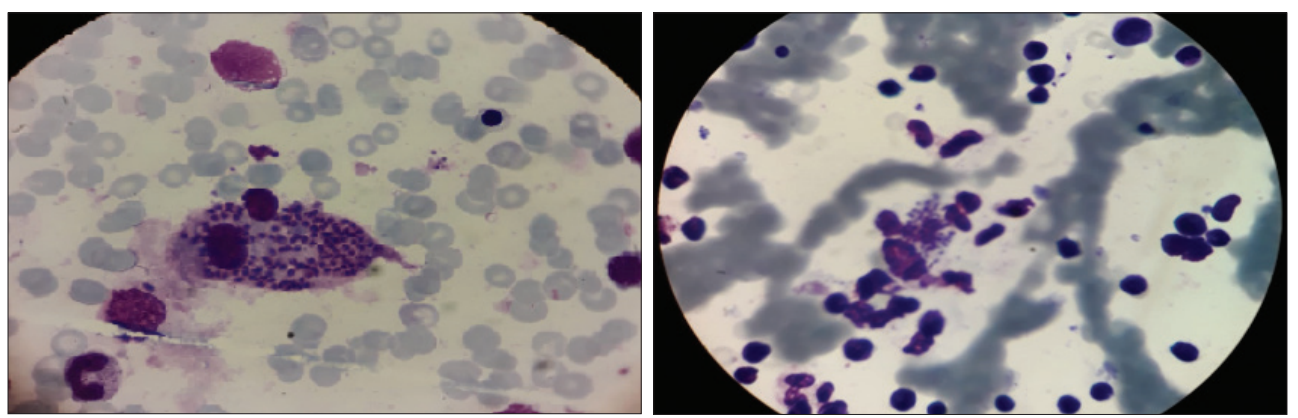

Resim 1. Kemik iliği aspirasyonunda hemofagositoz ve Leishmania fagosite etmiş makrofaj. 
Resim 2'de sunulmuştur. Ayrıca, hastadan alınan kemik iliği aspirasyon örneğine "Internal Transcribed Spacer 1 (ITS-1)" polimeraz zincir reaksiyonu (PCR) uygulandı ${ }^{14}$ ve etkene yönelik erime eğrisi analizi yapılarak L.infantum olarak tespit edildi. Eş zamanlı PCR'ye ait erime eğrisi grafiği Şekil 1'de verilmiştir.

Hastaya VL'ye sekonder HLH tanısı konarak, 5 mg/kg/gün dozunda intravenöz 5 gün ve tedavinin 10. gününde de tek doz olmak üzere lipozomal amfoterisin B uygulandı. Tedavinin beşinci gününde hastanın ateşi düştü. Halsizlik, yorgunluk, terleme şikayetlerinde belirgin azalma oldu. Tedavi sonrası ikinci ay yapılan kontrolünde hemoglobin düzeyi 12.3 $\mathrm{g} / \mathrm{dl}(11.7-16.0 \mathrm{~g} / \mathrm{dl})$, ortalama eritrosit hacmi (MCV) $84.6 \mathrm{fl}(81-101 \mathrm{fl})$, trombosit sayısı
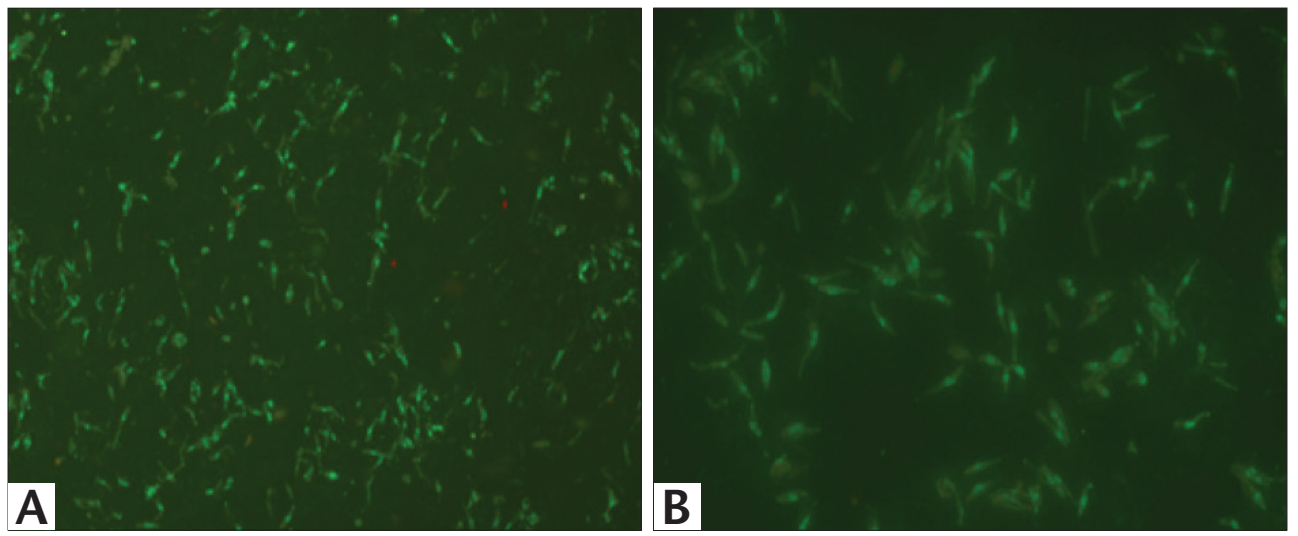

Resim 2. IFAT'ta pozitif serum örneğinin 1/16 seyreltmede A. x200, B. x400 büyütmede floresan mikroskopisindeki görüntüsü.

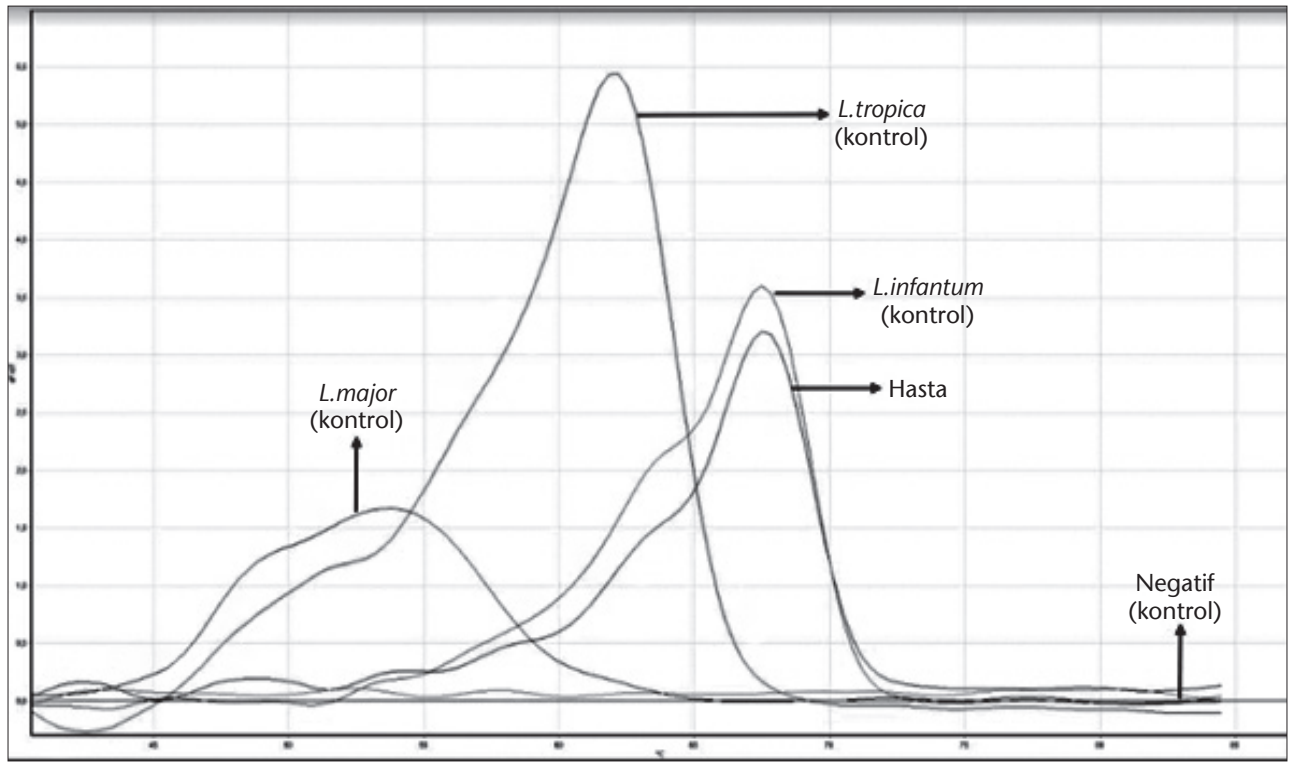

Şekil 1. Gerçek zamanlı ITS-1 PCR'ye ait erime eğrisi grafiği. 
$271 \times 10^{3} / \mu \mathrm{l}\left(150-450 \times 10^{3} / \mu \mathrm{l}\right)$, lökosit sayısı $6.58 \times 10^{3} / \mu \mathrm{l}\left(4.5-11 \times 10^{3} / \mu \mathrm{l}\right)$ şeklinde sonuçlandı. Hastanın serolojik izleminde ilk örnekten 3, 8 ve 10 ay sonra alınan serum örnekleri aynı IFAT'ta ileri seyreltmeleri yapılarak paralel çalışıldı. Üçüncü ve 8 . aya ait serum örnekleri $1 / 2048$ ve 10 . aya ait olan serum örneği $1 / 1024$ seyreltmede pozitif olarak saptandı.

\section{TARTIŞMA}

HLH, kontrolsüz immün aktivasyon, hipersitokinemi sonucu SIRS ile sonuçlanan bir klinik tablodur. Hastalar sıklıkla yoğun bakım hastasıdır ve tedavi edilmediği takdirde sonuç ölümcül seyretmektedir. HLH prevalansının düşük olduğu tahmin edilmekle birlikte, net bir değerlendirme bugüne kadar yapılamamıştır ${ }^{15}$. Klinik ve laboratuvar bulguları hastalığa özgül olmadığından uzun süreli açıklanmayan semptomları olan hastalarda hastalıktan şüphelenmek hayat kurtarıcı olacaktır. HLH farkındalığı arttıkça hastaların tanı alma şansı artacaktır. Hastamız da uzun süredir devam eden ateş yüksekliği ve sitopeni ile başvurmuş ve başvurusunda SIRS bulguları nedeniyle yoğun bakıma yatırılmıştır. Olgumuzda kontrol edilemeyen ateş, hepatosplenomegali, pansitopeni, ferritin yüksekliği ile HLH'den şüphelenilerek kemik iliği aspirasyon biyopsisi yapılmıştır. HLH için tanı kriterleri olan ateş, sitopeni, splenomegali, yüksek ferritin düzeyi, yüksek trigliserit düzeyi ve kemik iliğinde hemofagositoz tespit edilmesi üzerine HLH tanısı konulmuştur (Tablo I). Literatür incelendiğinde, HLH tanısında \%92-100 oranında yüksek ateş ve sitopeni ${ }^{16}$, \%60-100 splenomegali ${ }^{4}, \% 60-100$ hepatomegali ${ }^{4}, \% 30-40$ lenfadenomegali ${ }^{4}$ saptandığı görülmüştür.

HLH tanısı konulduktan sonra hastalığın etyolojisinde rol oynayan sekonder nedenler araştırılmalıdır. Hastamızda kemik iliği aspirasyon örneğinde hücre içi parazite rastlanması sonucunda sekonder nedenin saptanması için ipucuna rastlansa da, romatizmal hastalıklar, malignite, ilaçlar mutlaka araştırılmalıdır. Paraziter etkenlere bağlı HLH oldukça nadir görülmekte ve ilgili literatür tarandığı zaman paraziter etkenler olgu sunumları şeklinde karşımıza çıkmaktadır. Paraziter etkenler en sık Leishmania'ya bağlı olarak görülmektedir. Bugüne kadar $\mathrm{HLH}^{\prime}$ ye neden olan paraziter etkenler Leishmania ${ }^{17}$, Plasmodium ${ }^{18}$, Toxoplasma $^{19}{ }^{\text {, Babesia }}{ }^{20}$ ve Strongyloides ${ }^{21}$ olarak literatürde olgu sunumları olarak mevcuttur.

Leyşmanyazis; kutanöz leyşmanyazis (KL-Şark çıbanı, Halep çıbanı, güzellik çıbanı), VL (kala azar, kara hastalık, karahumma) ve mukokutanöz leyşmanyazis gibi üç klinik formu ile karşımıza çıkabilmektedir. VL retiküloendotelyal sistemi tutan bir hastalıktır ve hastalar kilo kaybı, ateş, splenomegali gibi klinik bulgularla hastaneye başvurmaktadır. Sıklıkla çocuklarda görülmesine rağmen, nadir de olsa erişkin hastalarda da görülebilmektedir. İmmün sistemi baskılayıcı hastalıklar nedeni ile son dönemlerde dünyada tekrar önemli soruna yol açan hastalıklardan biri olmuştur ${ }^{1}$. Tedavi edilmediğinde neredeyse tüm olgular ölümle sonuçlanmaktadır ${ }^{22}$. Olgumuz 50 yaşında olup ateş, kilo kaybı ve hepatosplenomegali mevcuttu. Yaşı nedeniyle hem HLH hem de VL için çok sık görülmeyen yaş grubunda HLH tanısı alan hastada sekonder neden olarak paraziter hastalıklar saptanabileceği gibi, VL tanısı alan ve tedavisi başlanan hastalarda düzelmeyen sitopeni devam 
eden ateş varlığında HLH geliştiği de akla gelmelidir. Nadir de olsa VL seyrinde HLH'ye olgu sunumları olarak literatürde rastlanmıştır ${ }^{23,24}$.

VL'de lipozomal amfoterisin B, terapötik etkinliği en yüksek ve en uygun güvenlik profiline sahip olan ilaçtır. Bu ilaç, monoterapi şeklinde $20-21 \mathrm{mg} / \mathrm{kg}$ olarak Avrupa, Kuzey Amerika ve Güney Amerika'da tercih edilen tedavi şeklidir ${ }^{25}$. Hastamızda intravenöz lipozomal amfoterisin B $5 \mathrm{mg} / \mathrm{kg} / \mathrm{gün}$ beş gün ve 10. gün $5 \mathrm{mg} / \mathrm{kg}$ tek gün şeklinde tedavide kullanılmıştır. İzlemde klinik ve laboratuvar değerlerinde anlamlı düzelme gözlenmiştir. Ferritin, trigliserit, fibrinojen, lökosit, hemoglobin, trombosit değerleri normal sınırlara dönmüş, klinik ve laboratuvar açısından stabil olan hasta kontrole gelmek üzere taburcu edilmiştir. Sonuç olarak, hem HLH hem VL erken tanı konulup tedavi edilmediğinde ölümcül olabilen hastalıklardır. Paraziter hastalıklar sekonder neden olarak mutlaka ayırıcı tanı açısından irdelenmelidir.

\section{ÇIKAR ÇATIŞMASI}

Yazarlar bu makale ile ilgili herhangi bir çıkar çatışması bildirmemişlerdir.

\section{KAYNAKLAR}

1. WHO Expert Committee on the Control of the Leishmaniases \& World Health Organization. (2010). Control of the leishmaniases: report of a meeting of the WHO Expert Commitee on the Control of Leishmaniases, Geneva, 22-26 March 2010. World Health Organization.

2. Kurşun E, Turunç T, Demiroğlu YZ, Solmaz S, Arslan H. Evaluation of fourteen adult cases with visceral leishmaniasis. Mikrobiyol Bul 2013; 47(3): 500-6.

3. Jeronimo SMB, de Queiroz Sousa A, Pearson RD. Leishmaniasis, pp: 696-706. In: Guerrant RL, Walker DH, Weller PF (eds), Tropical Infectious Diseases: Principles, Pathogens and Practice. 2011, 3rd ed. Saunders Elsevier, Philadelphia.

4. Ramos-Casals M, Brito-Zeron P, Lopez-Guillermo A, Khamashta MA, Bosch X. Adult haemophagocytic syndrome. Lancet 2014; 383(9927): 1503-16.

5. Marsh RA. Epstein-Barr virus and hemophagocytic lymphohistiocytosis. Front Immunol 2018; 8: 1902.

6. Buyse S, Teixeira L, Galicier L, Mariotte E, Lemiale V, Seguin A, et al. Critical care management of patients with hemophagocytic lymphohistiocytosis. Intensive Care Med 2010; 36(10): 1695-702.

7. Kumakura S, Murakawa Y. Clinical characteristics and treatment outcomes of autoimmune-associated hemophagocytic syndrome in adults: autoimmune-associated hemophagocytic syndrome. Arthritis Rheumatol 2014; 66(8): 2297-307.

8. Henter JI, Elinder G, Söder O, Ost A. Incidence in Sweden and clinical features of familial hemophagocytic lymphohistiocytosis. Acta Paediatr Scand 1991; 80(4): 428-35.

9. Clementi R, Emmi L, Maccario R, Liotta F, Moretta L, Danesino C, et al. Adult onset and atypical presentation of hemophagocytic lymphohistiocytosis in siblings carrying PRF1 mutations. Blood 2002; 100(6): 2266-7.

10. Nagafuji K, Nonami A, Kumano T, Kikushige Y, Yoshimoto G, Takenaka K, et al. Perforin gene mutations in adult-onset hemophagocytic lymphohistiocytosis. Haematologica 2007; 92(7): 978-81.

11. Shin HJ, Chung JS, Lee JJ, Sohn SK, Choi YJ, Kim YK, et al. Treatment outcomes with CHOP chemotherapy in adult patients with hemophagocytic lymphohistiocytosis. J Korean Med Sci 2008; 23(3): 439-44.

12. Bergsten E, Horne A, Arico M, Astigarraga I, Egeler RM, Filipovich AH, et al. Confirmed efficacy of etoposide and dexamethasone in HLH treatment: long-term results of the cooperative HLH-2004 study. Blood 2017; 130(25): 2728-38. 
13. Yıldız Zeyrek F, Dirim Erdogan D, Uluca N, Tumer S, Korkmaz M. Kutanöz leishmaniasis tanısında serolojinin yeri. Kafkas Univ Vet Fak Derg 2012; 18(Suppl-A): A121-A124.

14. Toz SO, Culha G, Zeyrek FY, Ertabaklar H, Alkan MZ, Vardarlı AT, et al. Real-time ITS1-PCR based method in the diagnosis and species identification of Leishmania parasite from human and dog clinical samples in Turkey. PLoS Negl Trop Dis 2013; 7(5): e2205.

15. Lemiale V, Valade S, Calvet L, Mariotte E. Management of hemophagocytic lympho-histiocytosis in critically ill patients. J Intensive Care Med 2020; 35(2): 118-27.

16. Creput C, Galicier L, Buyse S, Azoulay E. Understanding organ dysfunction in hemophagocytic lymphohistiocytosis. Intensive Care Med 2008; 34(7): 1177-87.

17. Watkins ER, Shamasunder S, Cascino T, White KL, Katrak S, Bern C, et al. Visceral leishmaniasis-associated hemophagocytic lymphohistiocytosis in a traveler returning from a pilgrimage to the Camino de Santiago. J Travel Med 2014; 21(6): 429-32.

18. Muthu V, Dhooria S, Singh Sehgal I, Agarwal R, Behera D, Varma N. Malaria-associated secondary haemophagocytic lymphohistiocytosis: report of two cases \& a review of literature. Indian J Med Res 2017; 145(3): 399-404.

19. Arayıcı S, Sarı FN, Yaralı N, Öncel MY, Kadıoğlu Şimşek G, Uras N, et al. Toxoplasmosis-associated hemophagocytosis in a preterm newborn. Turk J Haematol 2014; 31(3): 309-10.

20. Slovut DP, Benedetti E, Matas AJ. Babesiosis and hemophagocytic syndrome in an asplenic renal transplant recipient. Transplantation 1996; 62(4): 537-9.

21. Finkielman JD, Grinberg AR, Paz LA, Plana JL, Benchetrit GA, Nicastro MA, et al. Case report: reactive hemophagocytic syndrome associated with disseminated strongyloidiasis. Am J Med Sci 1996; 312(1): 37-9.

22. Desjeux P. Leishmaniasis. Public health aspects and control. Clin Dermatol 1996; 14(5): 417-23.

23. Rosado FG, Kim AS. Hemophagocytic lymphohistiocytosis: an update on diagnosis and pathogenesis. Am J Clin Pathol 2013; 139(6): 713-27.

24. Rajagopala S, Dutta U, Chandra KS, Bhatia P, Varma N, Kochhar R. Visceral leishmaniasis associated hemophagocytic lymphohistiocytosis--case report and systematic review. J Infect 2008; 56(5): 381-8.

25. Aronson N, Herwaldt BL, Libman M, Pearson R, Lopez-Velez R, Weina $\mathrm{P}$, et al. Diagnosis and treatment of leishmaniasis: clinical practice guidelines by the Infectious Diseases Society of America (IDSA) and the American Society of Tropical Medicine and Hygiene (ASTMH). Clin Infect Dis 2016; 63(12): e202-64. 